\title{
The Right to Jury Trial Under the Age Discrimination in Employment and Fair Labor Standards Acts
}

The Age Discrimination in Employment Act of 1967 (ADEA), ${ }^{1}$ though similar in substance to Title VII of the Civil Rights Act of $1964,{ }^{2}$ incorporates the enforcement scheme of the Fair Labor Standards Act (FLSA), ${ }^{3}$ a remedial statute of a different character. The hybrid nature of the ADEA and the loose wording of its enforcement provisions have contributed to a controversy over the right to jury trial in proceedings under the Act. The FLSA authorizes both private and public actions against employers who violate its standards. The courts have generally recognized a seventh amendment right to jury trial in actions to enforce private rights under section 16 of the FLSA, ${ }^{4}$ but they have denied the right in actions brought by the Secretary of Labor under section $17 . .^{5}$ The courts have also agreed that no seventh amendment right attaches in actions brought under

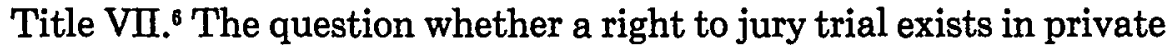
actions under the ADEA reached a court of appeals for the first time in Morelock v. NCR Corp. ${ }^{7}$ where the Sixth Circuit ruled that the seventh amendment did not confer a right to jury trial. Two months later the Fourth Circuit reached the opposite result in Pons $v$. Lorillard. ${ }^{8}$ Two district courts, relying on precedents under the

' 29 U.S.C. $\$ \S 621-634$ (1970 \& Supp. IV 1974).

242 U.S.C. $\$ \S 2000$ e to $2000 \mathrm{e}-17$ (1970 \& Supp. IV 1974). "With a few minor exceptions the prohibitions of [the ADEA] are in terms identical to those of the Civil Rights Act of 1964 except that 'age' has been substituted for 'race, color, religion, sex, or national origin.'" Hodgson v. First Fed. Savings \& Loan Ass'n, 455 F.2d 818, 820 (5th Cir. 1972). The major question in developing and construing defenses and burdens of persuasion in ADEA cases is whether Title VII precedents do or should apply, or whether distinctions between the kinds of discrimination that the two statutes address require the development of independent rules to govern ADEA actions. See Note, The Age Discrimination in Employment Act of 1967, 90 HARV. L. REv. 380 (1976).

${ }^{3} 29$ U.S.C. $\$ \S 201-219$ (1970 \& Supp. IV 1974). The ADEA incorporates by reference $\S \S$ $16 \& 17$ of the FLSA. 29 U.S.C. $\$ 626(b)$ (1970).

- See, e.g., Lewis v. Times Publishing Co., 185 F.2d 457 (5th Cir. 1950).

s See, e.g., Wirtz v. Jones, 340 F.2d 901 (5th Cir. 1965); text and notes at notes 74-80 infra. Commentators have argued that defendants should also have a right to jury trial in actions under $\S 17$. See Note, Fair Labor Standards Act and Trial by Jury, 65 CoLum. L. REv. 514 (1965) [hereinafter cited as FLSA Jury Trial].

- See, e.g., King v. Laborers Int'l Union Local 818, 443 F.2d 273 (6th Cir. 1973); text and notes at notes $48-50$ infra.

7546 F.2d 682 (6th Cir. 1976); see text and notes at notes 118-35 infra.

s 549 F.2d 950 (4th Cir. 1977); see text and notes at notes 112-20 infra. 
FLSA, have denied the right to jury trial in ADEA actions brought by the Secretary of Labor. ${ }^{9}$

Although Supreme Court doctrine on the seventh amendment has been in flux, recent decisions suggest that the jury trial issue in suits to enforce statutory rights of action such as those under the ADEA should be resolved by a functional test, focusing on the degree of discretion committed to the court by the statute. This comment traces the development of this functional test, then uses the test to evaluate the jury trial precedents under the FLSA and to determine whether the seventh amendment right attaches in private and public suits under the ADEA.

\section{The Right to Jury Trial in Statutory Causes of Action}

The seventh amendment guarantees the right to jury trial in civil suits "at common law."10 By granting the right in actions at common law but not in suits in equity or admiralty, the amendment erects a historical test for the presence of a right to jury trial. As early as 1830 , however, the Supreme Court stated that the right to jury trial attaches not merely to suits recognized at common law but to all causes of action-including those created by statute-that involve legal claims. ${ }^{11}$ The assertion of a right to jury trial under statutory causes of action triggers essentially the same type of inquiry as that required for nonstatutory civil actions.

Until fairly recently this inquiry was a strictly historical one. ${ }^{12}$ Prior to the merger of law and equity, ${ }^{13}$ the courts determined the

- Brennan v. International Harvester Co., 7 Empl. Prac. Dec. 6904 (N.D. Ill. 1974); Hodgson v. Bowman, 4 Empl. Prac. Dec. 5379 (E.D. Tenn. 1971); see text and notes at notes 143-49 infra.

${ }_{10}$ The seventh amendment provides:

In Suits at common law, where the value in controversy shall exceed twenty dollars, the right of trial by jury shall be preserved, and no fact tried by a jury shall be otherwise re-examined in any Court of the United States, than according to the rules of common law.

U.S. Const. amend. VII. The seventh amendment has never been held binding on the states through the fourteenth amendment. See Curtis v. Loether, 415 U.S. 189, 192 n.6 (1974).

1 Parsons v. Bedford, 28 U.S. (3 Pet.) 433, 447 (1830). The Parsons doctrine could have been limited in application to causes of action brought pursuant to Louisiana law. Since civil law claims are necessarily statutory, they may be more similar to common law claims than are the rights created by statute in common law jurisdictions. Nevertheless, the courts have never seriously questioned the notion that statutory causes of action may be legal in nature. See, e.g., Fleitmann v. Welsbach Street Lighting Co., 240 U.S. 27 (1916) (action for treble damages under $\S 7$ of the Sherman Act).

12 "In order to ascertain the scope and meaning of the Seventh Amendment, resort must be had to the appropriate rules of the common law established at the time of the adoption of that constitutional provision in 1791." Dimick v. Schiedt, 293 U.S. 474, 476 (1935).

13 Rule 2 of the Federal Rules of Civil Procedure provides: "[T] here shall be one form of action to be known as 'civil action.' " FED. R. Crv. P. 2. 
right to jury trial by conforming their practice to that of the courts in 1791, the time the seventh amendment was adopted.14 After the merger, courts at first followed the strict historical practice as closely as possible. If the complaint joined legal and equitable claims based on common factual issues, the court looked to historical practice to identify the nature of the basic issue in the suit in order to determine whether the right to jury trial was present. ${ }^{15}$ If the legal claims were merely incidental to the equitable relief sought, analogy to the historic cleanup jurisdiction of equity would indicate a bench trial of all issues. ${ }^{16}$ Recent developments in the law of jury trial have altered this historical test.

\section{A. From Beacon Theatres, Inc. v. Westover to Ross v. Bernhard}

The Supreme Court began to depart from the historical test for the seventh amendment right in Beacon Theatres, Inc. $v$. Westover. ${ }^{17}$ The plaintiff, threatened by the prospect of a treble damages antitrust action by Beacon Theatres, Inc., sought a declaratory judgment on the antitrust issues and a preliminary injunction to restrain Beacon from filing suit pending the outcome of the declaratory judgment action. Beacon brought an antitrust counterclaim and demanded a jury trial. The district court viewed the issues raised by the complaint as essentially equitable and ordered that they be tried without a jury before holding a jury trial of the issues raised by the counterclaim. ${ }^{18}$ The defendant appealed, asserting that this ordering of the proceeding would, by collateral estoppel, effectively foreclose a jury trial on issues common to the complaint and the counterclaim.

The court of appeals read the complaint as a plea for an injunction and noted that a premerger court of equity could have taken jurisdiction over the whole case, including the legal counterclaims, so that the dispute could be settled in a single action. ${ }^{18}$ Since the defendant would have had no effective seventh amendment right under premerger practice, the court of appeals reasoned that the trial court had not abused its discretion in ordering the proceedings in a way that would deny a jury trial.

"See note 12 supra.

15 For a discussion of the nature of the basic issue test, see 5 Moore's Federal Practice I 38.16, at 153-162.9 (2d ed. 1976).

"See, e.g., Fitzpatrick v. Sun Life Assurance Co. of Canada, 1 F.R.D. 713 (D.N.J. 1941).

17359 U.S. 500 (1959).

is Id. at 503-04.

" 252 F.2d 864 (9th Cir. 1958), rev'd, 359 U.S. 500 (1959). 
The Supreme Court reversed, and Justice Black's opinion for a 5 to 3 majority cast doubt on the vitality of the historical test. The court explained that the scope of equitable relief is to be determined by "practical" considerations: the adequacy of legal remedies and the danger of irreparable harm. ${ }^{20}$ If procedural reforms create adequate legal remedies where none existed before, the historical availability of equitable relief is "immaterial." of Civil Procedure ${ }^{22}$ and the Declaratory Judgment Act ${ }^{23}$ enabled the parties in Beacon Theatres to litigate their legal and equitable claims in a single action in which jury trial was available, the traditional reasons for equitable jurisdiction over the legal issues did not apply. The court of appeals' reliance on equity's premerger cleanup jurisdiction was therefore inapposite. Rejecting reference to historical practice in determining the proper ordering of legal and equitable claims for trial under current procedures, the Supreme Court held that a trial court's "discretion is very narrowly limited and must, wherever possible, be exercised to preserve jury trial."24

The Court's shift away from history as the means of determining the scope of equity for seventh amendment purposes continued two years later in Dairy Queen, Inc. v. Wood. ${ }^{25}$ Dairy Queen claimed trademark infringement and sought an accounting for profits wrongfully obtained through the use of its trademark. Although the claim was plainly cognizable at law, ${ }^{26}$ the trial court denied the defendant a jury because the remedy sought-an accounting-was viewed as equitable in nature. Mr. Justice Black, again speaking for the Court, held that for seventh amendment purposes the nature of an accounting prayer must be determined by the ability of a jury to settle the accounts in question. An accounting is equitable only if the accounts are so complicated that a jury, and perhaps a jury assisted by a master, cannot resolve them. ${ }^{27}$ Dairy Queen thus indicates that the nature of a remedy may be altered by procedural

${ }^{20} 359$ U.S. at 506-07.

21 Id. at 507.

${ }^{22}$ See, e.g., FED. R. Crv. P. 18 (providing for liberal joinder of claims and remedies); FED. R. Crv. P. 13(a) (rule on compulsory counterclaims).

2528 U.S.C. $\$ \$ 2201-2202$ (1970).

24359 U.S. at 510.

${ }^{25} 369$ U.S. 469 (1962).

${ }^{26}$ Because the defendant franchisee was alleged to be in breach of the franchise contract, the claim sounded either in infringement or in contract, and the profits reaped under the trademark subsequent to the breach could have been viewed as flowing from the breach or from the wrongful continued use of the trademark. The Court did not view the theory of liability as important for its analysis.

2769 U.S. 469, 479 (1962). 
advances such as the availability of masters to assist juries. ${ }^{28}$ The result in the case invites the question whether any but the most complex claims for monetary remedies can ever be characterized as equitable. ${ }^{29}$

After Dairy Queen the inadequacy of a remedy at law appeared to mean the inadequacy of a jury to handle the specific questions of a particular suit. The case departs from the historical test and moves toward the flexible, functional approach long recommended by commentators. ${ }^{30}$ The scope of this new functional test was partially illuminated in Ross v. Bernhard. ${ }^{31}$ In Ross the Court ruled that the right to jury trial attaches in shareholder derivative suits, despite the equitable origin of such actions, if the underlying corporate claim asserted is legal in nature. Whether an issue is legal or equitable, the Court suggested in a footnote, "is determined by considering, first, the pre-merger custom with reference to such questions; second, the remedy sought; and, third, the practical abilities and limitations of juries." 32

This formulation suggests that the historical tests survive as a means for determining whether a jury trial is required. The Beacon Theatres and Dairy Queen opinions implied that in each case raising the jury trial issue, the court must inquire whether the reasons behind the historical distribution of jurisdiction apply. The Ross guidelines evidence a retreat from this position. ${ }^{33}$ Where historical practice and the nature of the remedy indicate a clear answer, the third, functional branch of the test might not be reached at all. ${ }^{34}$

${ }^{28}$ The Court found support for this point in Beacon: "It was settled in Beacon Theatres that procedural changes which remove the inadequacy of a remedy at law may sharply diminish the scope of traditional equitable remedies by making them unnecessary in many cases." Id. at 478 n.19.

One commentator views Dairy Queen as demanding such a conclusion. See 5 Moore's Federal Practice $\Uparrow$ 38.19, at 172.1 (2d ed. 1976).

${ }^{30}$ For some time commentators have questioned the use of such doctrines as the cleanup theory to determine the seventh amendment rights and have recommended a more flexible approach geared to the realities of judicial administration after the merger. See generally Levin, Equitable Clean-Up and the Jury: A Suggested Orientation, 100 U. PA. L. REv. 320 (1951); James, Right to Jury Trial in Civil Actions, 72 YALE L.J. 655 (1963).

31 396 U.S. 531 (1970).

${ }^{32}$ Id. at 538 n.10.

33 While the three-pronged test was enunciated in a footnote and is clearly dicta, the lower courts have uniformly followed it, and the Supreme Court followed it in Curtis v. Loether, 415 U.S. 189 (1974).

अ For example, in Pernell v. Southall Realty, 416 U.S. 363 (1974), the Court looked solely to historical practice in determining that eviction actions in the District of Columbia are triable to a jury. The Pernell case might have been decided differently had the Court used a functional analysis and inquired into the reasons for legislative creation of the summary eviction remedy, but the Court limited its inquiry to finding the modern eviction analogous 
Indeed, the courts have not followed the implications of Beacon and Dairy Queen in suits for money relief. ${ }^{35}$ The seventh amendment "revolution" has had little impact on nonstatutory actions for money relief.

The third Ross criterion may be influential primarily in cases arising under new statutory causes of action for money relief. To determine the legal or equitable nature of such a cause of action, the first two criteria stated in Ross require an analogy to a historical nonstatutory counterpart. ${ }^{36}$ This approach is fruitful where the historical analogy is close, ${ }^{37}$ but in many cases the new cause of action may fairly be analogized to both traditional equitable and common law predecessors. ${ }^{38}$

The Supreme Court's failure to cite any specific cases in support of the functional test in the Ross footnote left the character and significance of the test unclear. ${ }^{39}$ The reference to the "practical abilities and limitations of juries" recalls the Dairy Queen opinion, which was viewed at the time of Ross as effecting a one-way reform expanding the right to jury trial; ${ }^{40}$ however, the same language also

to common law actions trying the right to possession. The decision illustrates the point that in most cases the separate criteria of the Ross test are not discrete. Considerations of jury capability and the limitations on the power of common law courts to enforce in personam remedies gave rise to many of the heads of equity jurisdiction. For example, the complexity of the factual determinations in injunctive actions and actions involving "uses" made such disputes unsuited to trial by jury at law.

${ }^{35}$ The Dairy Queen decision has not been uniformly followed even in the area of substantive law which it addressed. The courts have been reluctant to recognize a right to jury trial in trademark infringement suits seeking an accounting. See, e.g., Coca-Cola Co. v. Cahill, 330 F. Supp. 354 (W.D. Okla. 1971), aff'd, 480 F.2d 153 (10th Cir. 1973); Coca-Cola Co. v. Wright, 55 F.R.D. 11 (W.D. Tenn. 1971). Nor did Dairy Queen magically convert the general nature of actions for an accounting. See, e.g., Bonnell v. Commonwealth Realty Trust, 363 F. Supp. 1392 (E.D. Pa. 1973), aff'd, 511 F.2d 1392 (3d Cir. 1975) (mortgagor's action against mortgagee for an accounting plus damages held equitable in nature).

3s See generally 5 Moore's Federal Practice If 38.11[7], at 128-128.4 (2d ed. 1976).

${ }^{37}$ For example, actions under $\S 501$ (b) of the Labor-Management Reporting and Disclosure Act of 1959, 29 U.S.C. $\$ 501$ (b) (1970), seeking an accounting of misappropriated union treasury funds have been held not to raise a legal claim. Local 92, Int'l Ass'n of Bridge Workers v. Norris, 383 F.2d 735 (5th Cir. 1967). In Norris, the court ruled that the duties imposed upon union officials by the statute are directly analogous to the duties of a trustee created by and enforceable in equity. The remedy does not "become so 'legal' as to compel jury intervention merely because the 'accounting' is inevitably in dollars." Id. at 741; accord, Nedd v. Thomas, 316 F. Supp. 74 (M.D. Pa. 1970).

${ }^{38}$ Title VII actions, for example, are often termed restitutionary in nature by courts denying jury trial. See, e.g., Johnson v. Georgia Highway Express, 417 F.2d 1122 (5th Cir. 1959). But analogy to the common law action for wrongful discharge was considered more persuasive in the Title VII back pay case of Ochoa v. American Oil Co., 338 F. Supp. 914 (S.D. Tex. 1972).

39 See Redish, Seventh Amendment Right to Jury Trial: A Study in the Irrationality of Rational Decision Making, 70 Nw. U. L. REv. 486, 523-25 (1975).

to Professor McCoid thought Dairy Queen and Beacon Theatres erected a test based on 
recalls cases in which the Court had denied a right to jury trial that would have obstructed statutory proceedings. ${ }^{41}$ These cases suggest that the functional test in Ross might be used to limit, as well as expand, the right to jury trial.

The language in the Ross footnote does not specify what kinds of "practical abilities and limitations of juries" are relevant. The functional test presumably encompasses considerations other than the difficulty of computational tasks. One factor considered by the lower courts in resolving the jury trial issue in back pay cases under Title VII is the discretionary nature of the relief contemplated by the statute..$^{42}$ The Supreme Court's use of this criterion in Curtis $v$. Loether ${ }^{43}$ to distinguish Title VII actions from Title VIII housing discrimination actions for seventh amendment purposes suggests its appropriateness.

\section{B. Curtis v. Loether}

The Curtis case involved a claim for actual and punitive damages arising from racial discrimination in residential renting in violation of section 812 of the Fair Housing Provisions of the 1968 Civil Rights Act. ${ }^{44}$ Failing to find an unambiguous congressional intent to provide for jury trial, ${ }^{45}$ the Court based its decision on the seventh amendment. Although the Court noted that actual and punitive damages are traditionally legal forms of relief, ${ }^{46}$ it sounded the caveat that "[w]e need not, and do not, go so far as to say that any award of monetary relief must necessarily be 'legal' relief." ${ }^{47}$ The

a jurisdictional principle-the inadequacy of a remedy at law-in place of the strict historical "jurisdictional results" test. The jurisdictional principle analysis, given a trend of procedural changes consistently expanding available legal avenues, would inevitably increase the province of jury trial. McCoid, Procedural Reform and the Right to Jury Trial: A Study of Beacon Theatres, Inc. v. Westover, 116 U. PA. L. Rev. 1 (1967).

"See NLRB v. Jones \& Laughlin Steel Corp., 301 U.S. 1 (1937) (no right to jury trial in administrative proceedings); Katchen v. Landy, 382 U.S. 323 (1966) (issues underlying recovery of voidable preference in a summary bankruptcy proceeding not triable to a jury).

${ }^{42}$ The discretion criterion employed in Title VII cases, see note 52 infra, may be viewed as a functional consideration or as a very general historical benchmark of equitable jurisdiction.

4315 U.S. 189 (1974).

43 U.S. at 191-92. In a footnote, Justice Marshall reserved the question whether Congress could have effectively denied jury trial in Title VII cases in spite of the seventh amendment by invoking the powers granted by $\S 2$ of the thirteenth amendment or $\S 5$ of the fourteenth amendment. Id. at $198 \mathrm{n} .15 ; c f$. Fitzpatrick v. Bitzer, 427 U.S. 445, 456 (1976) (eleventh amendment held "necessarily limited by the enforcement provisions of the Fourteenth Amendment").

4415 U.S. 189, 196 (1974).

47. Id. As examples of monetary relief that are not legal in nature, the Court cited Mitchell v. Robert DeMario Jewelry, Inc., 361 U.S. 288 (1960), and Porter v. Warner Holding Co., 328 
indicia of nonlegal monetary relief are suggested by the Court's effort to distinguish the remedy under section 812 from back pay under Title VII, a remedy that the lower courts have said carries no constitutional right to jury trial. ${ }^{48}$ The Court first stated that the restitution analogy employed by some courts in characterizing the Title VII back pay remedy as equitable does not apply to monetary relief under section 812 , since such relief "[does not require] the defendant to disgorge funds wrongfully withheld from the plaintiff." 49 Second, the language of the enforcement provision in Title VII commits the back pay question to the discretion of the trial judge, ${ }^{50}$ but no "comparable discretion" is granted by section 812 : a plaintiff who proves discrimination and actual damages "is entitled to judgment for that amount."

Curtis involves no departure from the approach suggested in Ross-indeed, the Court followed the three-pronged Ross analysis-but the opinion does clarify how that approach should be applied to statutory causes of action for monetary relief. The Court seemed implicitly to approve the approach of the lower courts denying the right to jury trial in back pay actions under Title VII on the ground that the statute authorizes the trial court to exercise discretion in granting relief. ${ }^{52}$ The petitioner in Curtis argued from the

U.S. 395 (1946). The DeMario case, decided prior to the 1961 amendment to $\$ 17$ of the FLSA authorizing a backpay compensation order, concerned the power of the trial court in suits by the Secretary of Labor under $\S 17$ to order disbursement of wages lost due to an employer's unlawful discharge. Warner concerned the propriety of court-ordered restoration of rental overcharges in actions brought by the Price Administrator under the Emergency Price Control Act of 1942, ch. 26, § 205(a), 56 Stat. 33. Neither case involved the right to jury trial; their concern was the scope of equitable jurisdiction allowed to district courts hearing actions brought pursuant to statutes authorizing administrators to seek injunctive relief. The decisions stand for the proposition that absent clear congressional intent to the contrary, the district courts are empowered by implication from the jurisdictional grant to exercise plenary equitable jurisdiction. In the jury trial cases under $\S 17$ of the FLSA, courts have cited DeMario and Warner to support the holding that an injunction to restrain further withholding of minimum wages is an equitable remedy. See, e.g., Wirtz v. Jones, 340 F.2d 901 (5th Cir. 1965).

${ }^{4}$ See, e.g., Slack v. Havens, 522 F.2d 1091 (9th Cir. 1975); Johnson v. Georgia Highway Express, Inc., 417 F.2d 1122 (5th Cir. 1969). See generally Comment, Jury Trial in Employment Discrimination Cases-Constitutionally Mandated? 53 TEx. L. Rev. 483 (1975); Comment, The Right to Jury Trial Under Title VII of the Civil Rights Act of 1964, 37 U. CHI. L. REv. 167 (1969).

19 415 U.S. 189, 197 (1974).

so "[T] he court may enjoin the respondent from engaging in such unlawful employment practice, and order such affirmative action as may be appropriate, which may include reinstatement or hiring of employees, with or without back pay . . ." 42 U.S.C. § $2000 \mathrm{e}-5(\mathrm{~g})$ (1970).

st 415 U.S. at 197.

s2 "[T] issues present in these cases are purely equitable. As seen by the Act itself 
language of section $812(\mathrm{c})$, providing that the court "may grant" damages, that relief under that section was also discretionary with the court and therefore equitable. ${ }^{53}$ The Supreme Court apparently accepted the validity of discretion as a criterion, but rejected the argument that the statutory language left the relief to the trial judge's discretion. . $^{4}$

Curtis suggests that where the historical tests are not helpful, the nature of a suit or claim for seventh amendment purposes is to be determined by asking whether the statute creating the cause of action makes relief mandatory or discretionary with the court. ${ }^{55}$ The exercise of discretion in granting relief in a statutory cause of action is a function for which juries are unsuited; no matter how simple the computational tasks involved, a jury is not equipped to evaluate and implement legislative policies in shaping an award..$^{58}$ The dis-

the right to recover any money judgment at all is optional with the court." Culpepper v. Reynolds Metal Co., 296 F. Supp. 1232, 1241 (N.D. Ga. 1968), rev'd on other grounds, 421 F.2d 888 (5th Cir. 1970). The Fifth Circuit adopted the discretion rationale for denying jury trial in Title VII cases in Johnson v. Georgia Highway Express, Inc., 417 F.2d 1122 (5th Cir. 1968): "The demand for back pay is not in the nature of a claim for damages, but rather is an integral part of the statutory equitable remedy, to be determined through the exercise of the court's discretion and not by a jury." Id. at 1125 .

ss The theory of the discretion rationale was well expressed in the petitioner's brief:

There is no absolute right to actual or punitive damages such as existed at common law, for these matters are entrusted to the discretion of the court. "The distinguishing characteristics of legal remedies are their uniformity, their unchangeableness or fixedness, their lack of adaption to circumstances, and the technical rules which govern their use." 1 Pomeroy, Equity Jurisprudence $\$ 109$ (5th ed. 1941). Equitable remedies, on the other hand, were distinguished by their flexibility and variety [citation omitted].

Brief for Petitioner at 37, Curtis v. Loether, 415 U.S. 189 (1974).

34415 U.S. at 197.

ss At least one member of the Court has indicated that the discretion criterion follows from Curtis. In his concurring opinion in Albemarle Paper Co. v. Moody, 422 U.S. 405 (1976), Justice Rehnquist addressed the problem of the right to a jury trial in Title VII actions although the issue was not before the Court. In Albemarle the Court circumscribed the scope of discretion allowed trial court judges to withhold Title VII back pay relief. Citing Curtis, Justice Rehnquist commented:

To the extent, then, that the District Court retains substantial discretion as to whether or not to award backpay notwithstanding a finding of unlawful discrimination the nature of the jurisdiction which the court exercises is equitable and under our cases neither party may demand a jury trial. To the extent that discretion is replaced by awards which follow as a matter of course from a finding of wrongdoing, the action of the court in making such awards could not be fairly characterized as equitable in character, and would quite arguably be subject to the provisions of the Seventh Amendment.

Id. at 443 (Rehnquist, J., concurring).

s As a rule, equitable discretion is most necessary where injunctive relief is sought.

[E]xperience has shown that in the administration of specific relief there must be more discretion vested in the judge than in the allowance of money damages for the injury suffered. In the latter there can never be any greater injury inflicted on defendant by allowing recovery than would be inflicted on the plaintiff by denying it. But it very often 
cretion principle ${ }^{57}$ is best understood as a refinement of the functional test enuciated in Ross, particularly applicable in new statutory actions in federal court ${ }^{58}$ seeking monetary awards-actions

happens that the award of specific relief would inflict a hardship on the defendant which

is out of all proportion to the injury its refusal would cause to plaintiff.

H. McLinTock, EQUTTY 51-52 (2d ed. 1948). In actions brought pursuant to a statute, the interests of third parties and of the public as expressed in the legislative policy must be weighed in the calculus of injury. Indeed, one important aspect of equity jurisprudence is its willingness to look beyond the parties before it. See, e.g., the celebrated case of Jerome v. Ross, 7 Johns. Ch. 315, 11 Am. Dec. 484 (N.Y. 1823), in which Chancellor Kent weighed, perhaps too heavily, the public interest in the completion of the Erie Canal in denying injunctive relief to one whose property was being repeatedly raided for stone and rock by a canal construction crew.

${ }^{57}$ For criticisms of the discretion rationale employed in the Title VII cases, see Comment, The Seventh Amendment and Civil Rights Statutes: History Adrift in a Maelstrom, $68 \mathrm{Nw}$. U.L. REv. 503, 523-24 (1973), arguing that the chancellor had no monopoly on the exercise of discretion, since judicial discretion to reduce or enlarge jury damage awards was frequently exercised in patent litigation as well. A similar objection is raised in Redish, Seventh Amendment Right to Jury Trial: A Study in the Irrationality of Rational Decision Making, $70 \mathrm{Nw}$. U.L. REv. 486 (1975), noting the "uncontrolled" discretion often vested in juries to award damages in libel actions under the presumed damages doctrine. Id. at 529.

Discretion to deny an award is arguably a different matter from discretion to adjust. Nevertheless, the handiness of examples of discretionary justice-whether exercised by judge or jury-in common law actions does not lead to the conclusion that the criterion is not a suitable and roughly accurate distinction between law and equity for seventh amendment purposes. Any workable line of division must be broad; rough accuracy and ease of application are the appropriate goals a criterion must meet.

${ }^{38}$ The Supreme Court has recently distinguished for seventh amendment purposes between actions brought before Article III courts and actions before administrative agencies. See Atlas Roofing Co. v. Occupational Health \& Safety Review Comm'n, 97 S. Ct. 1261 (1977). In holding that the seventh amendment did not require a right to a jury trial in civil penalty adjudications by an administrative board, the Court stated:

[W] hen Congress creates new statutory "public rights," it may assign their adjudication to an administrative agency with which a jury trial would be incompatible, without violating the Seventh Amendment's injunction that jury trial is to be "preserved" in "suits at common law." . . . This is the case even if the Seventh Amendment would have required a jury where the adjudication of those rights is assigned instead [sic] to a federal court of law instead of an administrative agency.

Id. at 1269 (emphasis added).

The Court may have limited its holding to "new statutory public rights" in response to the plaintiff's contention that a decision denying the right to a jury trial would allow Congress to emasculate the seventh amendment by providing administrative fora for causes of action traditionally heard by juries. The validity and significance of this limitation are questionable, however. The Court does not sufficiently explain what constitutes a public right or why the public nature of a right should be important for seventh amendment purposes. See text and notes at notes $83-85$ infra. The limitation to cases involving newly created rights may be supported by the amendment's use of the term "preservation," but such sensitivity to the language of the amendment represents a new departure for the Court. The notion that new causes of action fall outside the ambit of the seventh amendment is irreconcilable with the doctrine, traceable to Parsons, that new statutory actions are to be analogized to historical nonstatutory counterparts to determine the right to jury trial. See text and note at note 36 supra; Curtis v. Loether, 415 U.S. 189, 193-94 (1974). But see NLRB v. Jones \& Laughlin Steel 
such as those created by the enforcement provisions of the FLSA and the ADEA.

\section{The Right to Jury Trial in FLSA Actions}

\section{A. The Enforcement Provisions of the FLSA}

The employment standards of the Fair Labor Standards Act ${ }^{59}$ are enforceable in three kinds of civil suits in the district courts. Section 16(b) authorizes affected employees to bring an action on behalf of themselves and other employees similarly situated ${ }^{80}$ to recover unpaid overtime compensation or unpaid minimum wages, plus an equal amount as "liquidated damages." 61 Under section 16(c), the Secretary of Labor is authorized to "supervise the payment of unpaid minimum wages or the unpaid overtime compensation owed to employees." 62 An employee who consents to accept such payment automatically waives any remaining rights under subsection (b). ${ }^{63}$ Section 16 (c) also empowers the Secretary to bring suit in district court to collect sums owed, including liquidated damages. The right of any employee to bring an action under subsection (b) terminates when the Secretary files a complaint under subsection (c). ${ }^{64}$ The public enforcement provision, section 17, authorizes the Secretary to bring suits to enjoin an employer's violations of the Act and to seek the "restraint of any withholding of payment of minimum wages or overtime compensation" found by the court to be owed to employees under the Act. ${ }^{65}$ The filing of a

Corp., 301 U.S. 1, 48.49 (1937). Furthermore, if new statutory public rights merit no seventh amendment protection in administrative proceedings, the grounds for granting them such protection in proceedings before Article III courts seem weak. The Court's bifurcated scheme for seventh amendment analysis is an uneasy attempt to accommodate the necessities of administrative adjudication and the mandate of the seventh amendment. The compromise appears more practical than principled.

3) 29 U.S.C. \$\$206, 207 (1970).

$\infty 29$ U.S.C. \& 216 (b) (1970).

"Id. In addition, the court "shall . . a allow a reasonable attorney's fee to be paid by the defendant, and costs of the action." Id.

229 U.S.C. $\$ 216$ (c) (Supp. IV 1974).

29 U.S.C. \& 216(b) (1970).

" Id. Attorneys' fees and costs are not recoverable under $\S 16(\mathrm{c})$. The original subsection (c), added in 1949, ch. 736, $\S 14,63$ Stat. 919 , authorized an action by the Secretary only upon a written request by affected employees and limited such actions to issues of law that had been settled by the courts. The 1974 amendments, Pub. L. 93-259, $\S 26,88$ Stat. 73, deleted these requirements and authorized recovery of liquidated damages under this subsection.

w 29 U.S.C. $\$ 217$ (1970). The original $\$ 17$ did not specifically provide for injunctions against withholding unpaid compensation, but the courts found authority to issue injunctions in the equitable powers implied by the jurisdictional grant. See McComb v. Frank Scerbo \& 
complaint by the Secretary under section 17 forecloses the rights of employees to bring a subsequent action under section $16 .{ }^{66}$

The attitudes of the parties toward jury trials apparently depend on whether the plaintiff is a private party or the Secretary of Labor. Private plaintiffs often seek jury trials over the opposition of the employer defendants, ${ }^{67}$ who may fear that the allegedly wronged employee may evoke the sympathy of the jurors. In suits brought by the Secretary, employer defendants often seek a jury trial over the opposition of the Secretary plaintiff. ${ }^{68}$

\section{B. The Right to Jury Trial in Private FLSA Actions}

The right of private plaintiffs to jury trial in section 16(b) FLSA actions has never been seriously questioned. ${ }^{69}$ Under any current test the FLSA employee action involves purely legal issues. The action for unpaid statutory compensation plus liquidated damages is analogous to a common law contract action, and the form of relief is presumptively legal in nature. ${ }^{70}$ Moreover, nothing in the language of the enforcement provision indicates that the employees' rights are defeasible by equitable factors once a violation has been shown. Any employer violating the Act's standards by failing to pay overtime compensation or the minimum wage "shall be liable to the employee or employees affected."'71

\section{The Right to Jury Trial in FLSA Actions by the Secretary OF LABOR}

1. Actions Under Section 17. A more difficult question is

Sons, 177 F.2d 137 (2d Cir. 1949). Congress responded by prohibiting such awards, Fair Labor Standards Amendments Act of 1949, ch. 736, § 15, 63 Stat. 919, until 1961, when the statute was changed to explicitly authorize what is often called the "restitutionary injunction." Pub. L. 87-30, § 12(b), 75 Stat. 74 (1961) (codified at 24 U.S.C. $\$ 217$ (1970)). For a discussion of the history of the FLSA enforcement provisions, see FLSA Jury Trial, supra note 5, at 51516.

es 29 U.S.C. $\S 216(\mathrm{~b})$ (1970).

7 See, e.g., Lewis v. Times Publishing Co., 185 F.2d 457 (5th Cir. 1950); Olearchick v. American Steel Foundries, 73 F. Supp. 273 (W.D. Pa. 1947).

${ }^{6}$ See, e.g., Dunlop v. Darboian Enterprises, Inc., 410 F. Supp. 479 (E.D. Mich. 1975); Brennan v. J.C. Penney Co., 61 F.R.D. 66 (N.D. Ohio 1973); Brennan v. Board of Educ., 344 F. Supp. 79 (D.N.J. 1972); Wirtz v. L.A. Swann Oil Co., 293 F. Supp. 211 (E.D. Pa. 1968).

"S See, e.g., Lewis v. Times Publishing Co., 185 F.2d 457 (5th Cir. 1950); Olearchick v. American Steel Foundries, 73 F. Supp. 273 (W.D. Pa. 1947).

${ }^{70}$ See, e.g., Dairy Queen v. Wood, 369 U.S. 469 (1962); Beacon Theatres, Inc. v. Westover, 359 U.S. 500 (1959); Whitehead v. Shattuck, 138 U.S. 146 (1891). In Whitehead, the Court said, "[W]here an action is simply ... for the recovery of a money judgment, the action is one at law." Id. at 151.

"I 29 U.S.C. $\$ 216$ (b) (Supp. IV 1974). 
raised by the denial of jury trial to the defendants in actions brought by the Secretary of Labor under section 17 to restrain "any withholding"'72 of statutory compensation..$^{73}$ In the leading case of Wirtz $v$. Jones, ${ }^{74}$ the Fifth Circuit ruled that the Secretary's action for a "restitutionary" injunction is not akin to a common law action to collect a private debt, ${ }^{75}$ but is an entirely new cause of action "to correct a continuing offense against the public interest."76 Relying on language in the Supreme Court's opinion in Porter $v$. Warner Holding Co. ${ }^{77}$ holding that federal courts hearing a similar public enforcement suit ${ }^{78}$ have full equity jurisdiction to order monetary relief, the Fifth Circuit declared that the Secretary's action, brought to vindicate the public interest, is a wholly equitable proceeding. Private rights to unpaid compensation are extinguished when the Secretary files suit, even though the "money may pass from the employer into the pocket of the employee . . . ."79 Courts that have subsequently denied a right to jury trial in section 17 actions have generally adopted the "public right" rationale of the Jones decision. ${ }^{80}$

Commentators have criticized Jones and its progeny as inconsistent with the teaching of Beacon Theatres since Jones denies section 17 defendants the right to jury trial on the "legal" issue of liability for unpaid statutory compensation by characterizing the entire action as equitable. ${ }^{81}$ This criticism is based on the view that

7229 U.S.C. $\$ 217$ (1970).

73 The courts have held almost unanimously that $\S 17$ actions raise no issues triable to a jury. E.g., Paradise Valley Investigation \& Patrol Serv., Inc. v. Dunlop, 521 F.2d 1342 (9th Cir. 1975); Wirtz v. Wheaton Glass Co., 253 F. Supp. 93 (D.N.J. 1966); Mitchell v. MichiganU.S. Industrial Glove \& Laundry Co., 189 F. Supp. 411 (E.D. Mich. 1960). The single exception, it appears, is Wirtz v. Thompson Packers, Inc., 224 F. Supp. 960 (E.D. La. 1963), where the court found the compensation issue in $\$ 17$ cases to be as fully "legal" as in $\S 16$ employee actions.

" 340 F.2d 901 (5th Cir. 1965). The Jones decision was expressly followed in Sullivan v. Wirtz, 359 F.2d 426 (5th Cir.), cert. denied, 385 U.S. 852 (1966).

75 "In the instant case, however, the purpose of the injunction to restrain the withholding of wages due is not to collect a debt owed by an employer to his employee . . . "340 F.2d 901, 904 (5th Cir. 1965).

740 F.2d at 904.

$\pi 328$ U.S. 395 (1946).

${ }^{73}$ In Porter, suit was brought under the Emergency Price Control Act of 1942, ch. 26, $\S$ 205, 56 Stat. 33.

730 F.2d at 904 .

so See, e.g., Brennan v. J.C. Penney Co., 61 F.R.D. 66 (N.D. Ohio 1973); Wirtz v. Wheaton Glass Co., 253 F. Supp. 93 (D.N.J. 1966).

\&I See FLSA Jury Trial, supra note 5. The Supreme Court passed up the opportunity to decide the question by denying certiorari in Sullivan v. Wirtz, 359 F.2d 426 (5th Cir.), cert. denied, 385 U.S. 852 (1966). Mr. Justice Black, author of the Beacon Theatres majority opinion, would have granted certiorari and ruled that defendants in FLSA Secretary actions are entitled to jury trial under the seventh amendment. 
the section 17 "restitutionary injunction" is a monetary remedy indistinguishable from the clearly legal award of unpaid overtime and minimum compensation in section 16 proceedings. ${ }^{82}$

As this criticism suggests, the "public right" theory of Jones is not entirely satisfactory. ${ }^{83}$ The presence of a public right does not supply an independent basis for denying the legal nature of the issues involved. Many-if not all-statutory actions implicate the public interest to some extent, yet the seventh amendment right to jury trial may exist in such actions. ${ }^{84}$ Indeed, when the government brings an action to collect a civil penalty, the seventh amendment has been held to confer the right to jury trial..$^{85}$ The attempt in Jones to characterize the section 17 suit by historical analogy is thus inconclusive.

An analysis more in line with recent Supreme Court decisions was employed by a district court in Dunlop v. Darboian Enterprises,

${ }^{82}$ In Wirtz v. Thompson Packers, Inc., 224 F. Supp. 960 (E.D. La. 1963), the district court observed:

Even though this demand is phrased in terms of an injunction restraining the withholding of compensation due the employees, it would be lending too much credence to form and ignoring the substance of the matter to argue that the action is not one for money damages in the guise of back wages. From defendant's point of view then, the interests of the employees are as much in controversy here as if their individual names appeared in the pleadings as parties to the action.

Id. at 962-63. Similarly, FLSA Jury Trial, supra note 5, argues that the remedies of $\S 16$ and $\S 17$ are indistinguishable. "Just as terms of equity in a complaint cannot foreclose the right to jury trial if a legal issue is involved, comparable language in a statute cannot obscure the legal nature of the relief authorized." Id. at 522.

8 The Supreme Court added a confusing new dimension to the significance of classifying a cause of action as a "public right" in Atlas Roofing Co. v. Occupational Health \& Safety Review Comm'n, 97 S. Ct. 1261 (1977). The Court held that Congress could commit the enforcement of "new statutory public rights" to administrative proceedings incompatible with jury trial, even though the seventh amendment would require a rights to jury trial if Congress committed the enforcement of those same rights to Article III courts. The opinion does not precisely define public rights or give a rationale for treating them differently from other rights. Atlas could be interpreted as undermining Jones by indicating that the public nature of a right is irrelevant if the right is enforced in an Article III court. Alternatively, Atlas might be viewed as reinforcing the validity of a distinction between public and private rights for seventh amendment purposes. See also note 58 supra.

st See Comment, The Seventh Amendment and Civil Rights Statutes: History Adrift in a Maelstrom, 68 Nw. U.L. REv. 503, 517-20 (1973). The author points out that the "public right" rationale for characterizing a proceeding as equitable, a notion stemming from the public rights doctrine developed in NLRB cases, would operate to deny jury trial in federal securities and antitrust actions, which are presumed to involve offenses against the "public right."

${ }^{85}$ See 5 Moore's Federal Practice If 38.31[1], at 232-33 (2d ed. 1976). It has been held, for example, that a defendant in an FTC action under $\S 5(l), 15$ U.S.C. $\$ 45(l)(1970)$, has the right to a jury determination of the question whether he violated an FTC order. United States v. J.B. Williams Co., 498 F.2d 414 (2d Cir. 1974); United States v. Hindman, 179 F. Supp. 926 (D.N.J. 1960). 
Inc. ${ }^{86}$ Heeding the suggestion in Curtis that the discretion of the trial judge is an indicator of equitable jurisdiction, that court held that section 17 relief is equitable in nature since it is discretionary with the bench. ${ }^{87}$

The district court's interpretation of Curtis validates the Jones result, if not its reasoning. Section 17 provides that the district courts:

Shall have jurisdiction for cause shown, to restrain violations of section 15, including in the case of violations of section 15(a)(2) the restraint of any withholding of payment of minimum wages or overtime found by the court to be due to employees under this Act. ${ }^{88}$

The Darboian court found that both the descriptive title of the section, "Injunctions," and the language of restraint indicated that equitable powers were vested in the district courts. ${ }^{80}$ Both the com-

st 410 F. Supp. 479 (E.D. Mich. 1975).

87 Id. at 481 .

ss 29 U.S.C. \& 217 (1970).

"That an action is termed "equitable" by the legislature does not necessarily indicate that relief is to be discretionary with the court or that a functional justification exists for bench trial. For a court to give such a legislative label conclusive effect for seventh amendment purposes is an abdication of the judiciary's role as guarantor of constitutional rights. However, commentators concerned about potential expansion of the right to jury trial in the federal courts as a result of Beacon Theatres and Dairy Queen have recommended deference to congressional labels. See Redish, Seventh Amendment Right to Jury Trial: A Study in the Irrationality of Rational Decision Making, 60 Nw. U.L. REv. 486 (1975); Note, Congressional Provision for Nonjury Trial, 83 YALE L.J. 401 (1973). A frequent rationalization of such deference is rooted in the "practical abilities and limitations of juries" language of the third prong of the Ross test. The theory is that since the Court has already indicated the propriety of considering such procedural impediments to trying an action on the "law side," it is no major leap to recognizing a legislative determination of the adequacy of remedies at law. If the statute contemplates bench trial, it can be presumed that Congress determined that a jury is a significant impediment to the proper adjudication of the suit.

The Supreme Court implictly rejected this approach in Pernell v. Southall Realty, 416 U.S. 363 (1974). In Pernell, the circuit court had found a legislative intent that eviction proceedings brought under $\S 16-1501$ of the District of Columbia Code be tried without a jury. The Supreme Court considered this interpretation binding, but ruled that the seventh amendment required a jury trial in such actions. On the other hand, language in the Court's recent opinion in Atlas Roofing Co. v. Occupational Safety \& Health Review Comm'n, 97 S. Ct. 1261 (1977), could be interpreted as deferring to a congressional determination of adequacy:

We cannot conclude that the Amendment rendered Congress powerless-when it concluded that remedies available in courts of law were inadequate to cope with a problem within Congress' power to regulate-to create new public rights and remedies by statute and commit their enforcement, if it chose, to a tribunal other than a court of law-such as an administrative agency-in which facts are not found by juries.

Id. at 4317. The limitations the Court imposed on this congressional power-that the vesting of adjudicatory powers in administrative agencies must be limited to instances in which 
pensation order and the injunction against future violations issue for "cause shown." An order compelling payment is not automatic upon a finding that compensation was not paid, but issues only after an equitable balancing similar to that governing the issuance of an order enjoining future violations..$^{90}$

The existence and degree of trial court discretion to restrain the withholding of proper compensation under section 17 have been controversial. The Secretary has consistently urged that a "restitutionary injunction" must issue as a matter of course upon a showing that the Act has been violated. ${ }^{91}$ Yet, while the circuits agree that the trial court's discretion is narrowly circumscribed ${ }^{82}$ no court has denied the existence of such discretion. ${ }^{93}$ The arguments in favor of mandatory monetary relief-that failure to afford such

Congress creates new public rights-counsel against such an expansive reading. If the rights involved were private or established (as opposed to new) the Atlas rationale would not permit deference to a congressional determination of the inadequacy of legal remedies. See note 58 supra.

${ }^{90} 410$ F. Supp. at 481 . "Cause shown" is defined as "such cause as would move a court of equity to protect employees against future violations or threats to violate." Walling v. T. Buettner \& Co., 133 F.2d 306, 307 (7th Cir.), cert. denied, 319 U.S. 771 (1943) (insufficient cause shown for enjoining future violations where the defendant acted in good faith).

"The Secretary unsuccessfully urged this position in the following cases: Brennan v. J.M. Fields, Inc., 488 F.2d 443 (5th Cir. 1974); Hodgson v. Taylor, 439 F.2d 288 (8th Cir. 1971); Schultz v. Mistletoe Express, Inc., 434 F.2d 1267 (10th Cir. 1970); Schultz v. Parke, 413 F.2d 1364 (5th Cir. 1969); Wirtz v. Wershow Co., 416 F.2d 1071 (9th Cir. 1969).

"2 The narrowing process evident in the cases occasioned this judicial comment: "I am content to leave to another panel in another case the holding, clearly foreshadowed by the decided cases, that injunctive relief in this situation should issue as a matter of course." Schultz v. Parke, 413 F.2d 1364, 1370-71 (5th Cir. 1969) (Simpson, J., concurring). Indeed, the Supreme Court in Mitchell v. Robert DeMario Jewelry, Inc., 361 U.S. 288 (1959), observed that "because of what we have found to be the statutory purposes there is doubtless little room for the exercise of discretion not to order reimbursement . . . ." Id. at 296. The significance of this remark is limited by the fact that DeMario was an illegal discharge case. The statutory purposes demand a much narrower scope for trial court discretion in discharge cases than in the typical overtime compensation case, since recriminatory discharges radically threaten the viability of private enforcement.

${ }^{93}$ In Wirtz v. Malthor, Inc., 391 F.2d 1 (9th Cir. 1968), the Ninth Circuit reversed a district court's determination that a monetary injunction was improper as against the public interest and ordered the lower court to enter the order to "protect those employers who comply with the Act from having to compete unfavorably with employers, who do not comply." Id. at 3. The court thought the order especially important since private rights of action are cut off when the Secretary files suit. It is not clear from the opinion whether the court reversed on the ground of error of law or on the ground of abuse of discretion. Whatever may have been the Ninth Circuit's position at that time, it is clear after Brennan v. Saghatelian, 514 F.2d 619 (9th Cir. 1975), which affirmed the denial of the order upon a balancing of the equities, that the circuit now views the award as discretionary. In response to the contention that the statute grants the trial court no discretion, the court stated that "we cannot conclude that they [prior decisions and the purposes of the FLSA] force a court of equity to make an inequitable decree." Id. at 622. 
relief leaves employees remediless, and that unequal enforcement of standards gives noncomplying employers an unfair competitive advantage over complying employers-lose force when the employment relationship is viewed realistically. Employees frequently waive overtime compensation in exchange for wages in excess of the employer's competitors, allow prevailing "violations" to persist unremedied for years, or accede to technical violations in exchange for other benefits. An employer often believes in good faith that he is not in violation. In some cases, strict enforcement through a restitutionary injunction would threaten the jobs of the very employees the Act seeks to protect. ${ }^{94}$ Recognizing these prob 'ems with mandatory monetary relief, the district courts have refused to relinquish their discretion over awards of statutory compensation.

The discretion of the trial court-supported by the language and the policies of the statute-distinguishes actions by the Secretary under section 17 from private actions under section 16 . The trial judge in actions under section 17 is entrusted with a historically equitable role that juries are ill-equipped to perform. Under the discretion principle suggested in Curtis, the seventh amendment does not require jury trial in section 17 actions.

2. Actions Under Section 16(c). The Secretary brings actions under section 16(c) with relative infrequency, and usually for the purpose of recovering statutory liquidated damages thought to be unavailable under section $17 . .^{95} \mathrm{~A}$ suit under section $16(\mathrm{c})$ is essentially a representative action, brought to enforce the private rights described in section $16(\mathrm{~b}) .{ }^{98}$ Courts have accordingly recognized the right to jury trial in these actions. ${ }^{97}$

A difficulty arises when the Secretary joins a section 16(c) claim with a section 17 claim in order to obtain liquidated damages in addition to injunctive relief and "restitution." In such cases the Secretary generally claims unpaid statutory compensation under

" For a complex of such circumstances justifying the denial of an injunction, see Brennan v. Saghatelian, 514 F.2d 619, 621 (9th Cir. 1975). All FLSA actions are governed by the two-year limitation provided in $\S 6$ (a) of the Portal-to-Portal Act, 29 U.S.C. $\S 255$ (a) (1970). Nevertheless, plant-wide monetary relief computed from a date two years prior to the filing of a Secretary action could amount to a sum large enough to stagger a marginal firm.

ss Telephone interview with Gilbert Drucker, Counsel for Employment Standards Administration, Chicago Regional Office of the U.S. Department of Labor. Liquidated damages first became available in actions by the Secretary as a result of the 1974 amendments to $\S$ 16(c). See note 64 supra.

" Amendments to $\S 16(\mathrm{c})$ in 1974 made the section less like a representation action. See note 64 supra. Relief under $\S 16(c)$ as amended is almost indistinguishable from monetary relief under $\$ 17$, except for the availability of liquidated damages.

" See, e.g., Mitchell v. City Ice Co., 273 F.2d 560 (5th Cir. 1960). 
the section 16 count rather than under section $17,{ }^{98}$ and the compensation claim consequently becomes triable to a jury as of right.99 Since no statutory basis exists for treating section 16 relief as equitable, the Secretary appears to have the power to foreclose judicial discretion with respect to the compensation claim by simply denominating it a section 16 claim, but only if he is willing to allow the issue to be tried by a jury. ${ }^{100}$

\section{The Right to JURy Trial Under the ADEA}

\section{A. The Enforcement Provisions of the ADEA}

Although section 626(b) of the ADEA incorporates by reference sections 16 and 17 of the FLSA, ${ }^{101}$ the enforcement schemes of the two statutes differ in important respects. These differences in part reflect the reality that age discrimination and the failure to provide minimum working conditions cause different kinds of harm and affect different classes of people. For example, the typical private plaintiff under the FLSA is an employee suing his employer for unpaid minimum wages or overtime. Monetary relief is easy to calculate in such cases, and injunctions against future violations seem almost superfluous. On the other hand, a plaintiff under the ADEA might be one of several persons denied a particular job because of age. In this case the calculation of monetary compensation is more problematic, and injunctive relief may be more desirable.

Section 626(b) of the ADEA evades the monetary relief problem by providing that "[a]mounts owing to a person" as a result of a violation of the ADEA "shall be deemed to be unpaid minimum

9* Telephone interview with Gilbert Drucker, Counsel for Employment Standards Administration, Chicago Regional Office of the Department of Labor.

"Since common issues underlie the claim for liquidated damages and the claim for unpaid statutory compensation, Beacon Theatres would require an ordering of the trial that might effectively entail a jury determination of both claims. See text and note at note 24 supra.

${ }^{100}$ It is an open question whether the trial court has the power to reclassify the claims presented in mixed actions in accordance with its perception of the basic nature of the action. In Usery v. Venango Diagnostic \& Training Center, Inc., 72 F.R.D. 469 (W.D. Pa. 1976), a court faced with such a mixed action postponed ruling on the motion to strike the demand for jury trial until the pretrial conference when, it was hoped, it would become clear "whether the action is primarily equitable or an action for monetary damages." Id. at 470 . The defendant argued that the question of injunctive relief was moot, and therefore that the only issues remaining concerned monetary relief. The court seemed to imply that only if the injunctive claim remained in controversy would the minimum wage issue be tried to the bench under the guise of "restitution."

101 "The provisions of this chapter shall be enforced in accordance with the powers, remedies, and procedures provided in sections 211 (b), 216 (except for subsection (a) thereof), and 217 of this title, and subsection (c) of this section." 29 U.S.C. $\$ 626(b)$ (1970). 
wages or unpaid overtime compensation for the purposes of" sections 16 and 17 of the FLSA. ${ }^{102}$ The referent of "amounts owing" is unclear, but other language in section 626 suggests that Congress intended the courts to determine the available forms of relief, and thus the meaning of "amounts owing." After limiting the liquidated damages remedy to cases involving willful violations, section 626(b) gives the courts "[i]n any action brought to enforce this Act . . . jurisdiction to grant such legal or equitable relief as may be appropriate to effectuate the purposes of this Act." 103 This language can be interpreted as merely providing jurisdiction to hear the various types of FLSA actions, but the words might also be interpreted to authorize a court to grant a private plaintiff equitable remedies not available under section 16 of the FLSA or to grant the Secretary the full range of legal remedies available to private plaintiffs. Section 626 (c) provides that "any person aggrieved" may bring a civil action for "such legal or equitable relief as will effectuate the purposes of this chapter," and that the right to bring such an action terminates when the Secretary brings an action to enforce the right of "such employee."104 Although the use of the two terms "person" and "employee" creates some confusion, ${ }^{105}$ section $626(\mathrm{c})$ is probably best read together with section $626(\mathrm{~b})$ to include nonemployees among the potential private plaintiffs and to confirm that private plaintiffs may seek equitable as well as legal relief. ${ }^{106}$

The enforcement scheme of the ADEA also differs from that of the FLSA in relying more heavily on voluntary settlement machinery. Private plaintiffs must give the Secretary sixty days' notice before they bring suit so that the Secretary can initiate conciliation measures. ${ }^{107}$ Moreover, before the Secretary himself can bring a suit,

${ }^{102} \mathrm{Id}$.

10329 U.S.C. $\$ 626(\mathrm{~b})(1970)$.

in 29 U.S.C. $\$ 626(\mathrm{c})(1970)$.

1os The ADEA defines the term "person" broadly to include "individuals, partnerships, associations, labor organizations, corporations, business trusts, legal representatives, or any organized groups of persons." 29 U.S.C. $\$ 630(a)$ (1970). An "employee" is defined as "an individual employed by any employer . . . " 29 U.S.C. $\$ 630$ (f) (Supp. IV 1974).

100 If "person" is read to mean "employee," then individuals unable to obtain employment because of discrimination would arguably have no right to sue-a result inconsistent with the purpose of the Act. See 29 U.S.C. $\$ 621$ (1970). Since $\S 16(\mathrm{~b})$ of FLSA by its terms grants rights only to "employees" as defined in 29 U.S.C. § 203(e) (Supp. IV 1974)-a definition essentially identical to that in the ADEA-the rights of nonemployees under $\S$ 626(b) of the ADEA are uncertain. Allowing "any person aggrieved," rather than just employees, to bring an action is a potentially significant expansion of the class of possible plaintiffs. Yet, in spite of the confusing language and structure of $\S 626(\mathrm{~b})$ and (c), there seems little reason for treating actions by employees differently from actions by nonemployees.

10729 U.S.C. $\$ 626(d)(1970)$. 
he must attempt to "eliminate the discriminatory practice or practices alleged, and to effect voluntary compliance . . . through informal methods of conciliation, conference, and persuasion."'108

\section{B. The Right to Jury Trial in Private ADEA Suits}

The two circuits that have addressed the seventh amendment issue in private actions under the ADEA have reached conflicting results. In Morelock v. NCR Corp. ${ }^{100}$ the Sixth Circuit held that claims for back pay and for compensatory, punitive, and liquidated damages, joined with a prayer for reinstatement and injunctive relief, do not raise issues triable to a jury. The Fourth Circuit has more recently ruled in Pons $v$. Lorillard ${ }^{110}$ that a plaintiff claiming lost wages arising from a discriminatory discharge is entitled to a jury trial on that claim. ${ }^{111}$

The Fourth Circuit based its holding on three factors. First, the court noted that section 626 contemplates an action at law. Following the suggestion in Curtis that the language of the enforcement provision may be crucial for determining whether a right to jury trial exists, the court pointed out that the terminology of section 626 "comprises the power to grant legal relief," "112 a signpost of a suit at common law within the meaning of the seventh amendment. Second, the court looked to the language of section $626(\mathrm{~b})$ incorporating the enforcement provisions of the FLSA and concluded that "the Age Act clearly equates lost wages as [sic] 'unpaid minimum wages or unpaid overtime compensation under the FLSA.'"113 Since amounts owing under the FLSA give rise to claims uniformly held to be legal in nature and triable to a jury in private actions, a claim for lost wages under the ADEA is similarly a legal claim. Finally, applying the Ross test, the court ruled that the claim for lost wages was a traditionally legal claim by analogy to common law actions sounding in tort or breach of contract by wrongful discharge, and that the claim was well within the jury's competence. ${ }^{114}$ The joinder

108 29 U.S.C. $\$ 626(\mathrm{~b})(1970)$.
109 546 F.2d 682 (6th Cir. 1976).
110 549 F.2d 950 (4th Cir. 1977).
"11 The plaintiff in Pons also sought liquidated damages, but failed to request jury trial of that issue, apparently in the belief that liquidated damages is a bench issue. "The District Judge's opinion notes that the plaintiff 'conceded that the liquidated damages issue would not be triable to a jury." " 549 F.2d 950, 951 n.3 (1977). But in Cleverly v. Western Elec. Co., 69 F.R.D. 348 (W.D. Mo. 1975), it was correctly held that issues underlying the prayer for liquidated damages are triable to a jury as of right. See note 129 infra.

112549 F.2d 950 (4th Cir. 1977).

113 Id. at 953.

i' Id. at 954 . 
of the money claim with a prayer for reinstatement did not, in the court's view, render the remedy any less legal, since the rule of Dairy Queen requires that each claim be independently analyzed for the purpose of determining the right to jury trial. ${ }^{115}$

Although the court's opinion isolates several factors that strongly support the result reached, it fails to note ambiguities surrounding section 626 that might point to a contrary conclusion. In Curtis the Supreme Court differentiated the Title VII action from the Title VIII action on the ground that the former plainly vests the trial court with discretion in decreeing monetary relief. The Pons court quoted that portion of the Curtis opinion, but overlooked the significance of the Supreme Court's effort to distinguish Title VII. The court stated in a conclusory fashion that the ADEA "includes the terminology of a law action . . . rather than only a suit in equity to be decided and decreed by a chancellor," 116 but did not search the language of section 626 for evidence that the Act, like Title VII, commits the award of monetary relief to the discretion of the trial judge. ${ }^{117}$

The Sixth Circuit in Morelock $v$. NCR Corp. ${ }^{118}$ did examine the statute and, following the method of inquiry indicated by Curtis, held that since, in its view, section 626 vests in the trial court a degree of discretion similar to that provided by Title VII and FLSA section 17, the claims for back pay, damages, and reinstatement were all equitable. ${ }^{119}$ The decision effectively denies the right to jury trial on all issues raised in private actions under the ADEA. The Pons decision, and the leading district court cases finding a right to jury trial in private ADEA actions, are based primarily on precedents under section 16 of the FLSA. ${ }^{120}$ The Morelock court properly

is Id.

III Id. at 953.

11 The Pons concurrence noted Morelock in passing but made no reference to the reasoning on which that decision was based. 549 F.2d 953, 954 (4th Cir. 1977) (Butzner, J., concurring).

IIs 546 F.2d 682 (6th Cir. 1976).

i" The court did not consider the general availability of punitive and compensatory damages under the ADEA. Liquidated damages-an amount equal to the amounts owing as a result of an employer's violation-contain a punitive element. Like so many other issues arising under the Act, the question of what remedies are available and proper is quite open.

120 In Chilton v. National Cash Register Co., 370 F. Supp. 660 (S.D. Ohio 1974), the court stated that the congressional mandate that ADEA actions be deemed actions under FLSA $\S \S 16 \& 17$ made the right to jury trial under the ADEA "necessarily . . . dependent on whether such right exists for $\S 216$ or $\S 217$ claims." Id. at 664 . In Cleverly v. Western Elec. Co., 69 F.R.D. 348 (W.D. Mo. 1975), the FLSA precedents were given somewhat less force. The court buttressed its conclusion that back pay is legal by reference to the premerger characterization of claims under the FLSA provisions "made applicable to ADEA actions ...." Id. at 351 . 
discerned that the provisions of section 16(b) of the FLSA "must be considered in conjunction with those of [section 626(c) of the $\mathrm{ADEA}]$ in order to ascertain the nature of the issues presented in individual actions under the ADEA."121 The court noted that section 626(c) provides for private remedies, including equitable remedies, unavailable to employees suing under the FLSA. Furthermore, the court found that the broad language of subsections (b) and (c), which empowers the courts to "grant such legal and equitable relief as may be appropriate to effectuate the purposes of this chapter," ${ }^{122}$ compelled the conclusion that relief is discretionary with the court in both private and public suits.

In addition to its analysis of the statutory language, the Sixth Circuit marshalled several further considerations:

Appellants' action in this case is basically for reinstatement and injunctive relief. Such an action necessarily invokes the broad powers of the Court and is essentially equitable in nature. The monetary relief sought by the appellants is the equivalent of funds allegedly wrongfully withheld from them by NCR in the past, and is an integral part of the basic equitable claim for reinstatement. ${ }^{123}$

The mention of withholding of funds apparently refers to the restitution analogy that some courts invoke in back pay suits under Title VII. ${ }^{124}$ That analogy, a weak one for seventh amendment purposes in the context of Title VII, ${ }^{125}$ is even less persuasive in Morelock since the plaintiffs sought liquidated and punitive damages in addition to lost wages. ${ }^{126}$ The argument that monetary relief is a bench

${ }^{121}$ Morelock v. NCR Corp., 546 F.2d 682, 688 (6th Cir. 1976).

12229 U.S.C. $\$ \S 626(b)$, (c) (1970).

${ }^{123}$ Morelock v. NCR Corp., 546 F.2d 682 (6th Cir. 1976).

${ }^{124}$ See, e.g., Culpepper v. Reynolds Metals Co., 296 F. Supp. 1232 (N.D. La. 1969), rev'd on other grounds, 421 F.2d 888 (5th Cir. 1970).

${ }^{125}$ The characterization of the Title VII back pay remedy as restitutionary and therefore equitable suffers from two major defects. First, the award does not "restore" to the plaintiff anything wrongfully obtained by the employer, but rather protects an expectation interest. The Title VII back pay suit is akin to the common law action for breach of contract by wrongful discharge. See Ochoa v. American Oil Co., 338 F. Supp. 914, 918-19 (S.D. Tex. 1972). Second, even assuming that the action is restitutionary in nature, it is not necessarily equitable. Professor Corbin contends that restitution was available at law through an action indebitatus assumpsit. See 5A CorBin ON CoNTRACTS § 1103, at 1157 (1964 \& Supp. 1971).

${ }^{126}$ Restitutionary remedies are designed to restore plaintiffs to their position prior to the wrong complained of and never contain an exemplary element. "A person obtains restitution when he is restored to the position he formerly occupied either by the return of something which he formerly had or by the receipt of its equivalent in money. Ordinarily, the measure of restitution is the amount of enrichment received . . . " RESTATEMENT OF RESTiTution $\S 1$, at 12 (1937). Historically, equity courts would not award punitive damages. This limitation 
issue because it is "integral" to a basic equitable claim is also untenable. After Beacon Theatres the analogy to equity's cleanup jurisdiction affords no basis for denying jury trial when legal and equitable claims are joined in a complaint. The rule of that case cannot be circumvented by labeling the legal claims "integral" rather than merely incidental to the primary equitable claim.

The crux of the conflict between Pons and Morelock ${ }^{127}$ is the Morelock court's construction of the statute to arrive at the conclusion that relief is discretionary with the bench, even after the plaintiff has shown a violation of the Act. ${ }^{28}$ Neither Pons nor the district court decisions holding that a right to jury trial attaches in private $\mathrm{ADEA}$ suits ${ }^{129}$ adequately addresses the question whether section

is thought to flow from the principle that equity will not enforce penalties or forfeitures. See generally H. McLinTOcK, EQUTTY 81-84 (2d ed. 1948). Some jurisdictions have rejected the limitation since the merger of law and equity. See, e.g., I.H.P. Corp. v. 210 Central Park South Corp., 12 N.Y.2d 329, 239 N.Y.S.2d 546, 189 N.E.2d 812 (1963). However, the majority rule is that punitive damages may not be awarded in actions for equitable relief. See generally 63 CoLum. L. REv. 175 (1963). Lost wages and benefits are the only monetary relief available in Title VII actions. One court has ruled that plaintiffs seeking other damages must proceed under other statutes, in part because no jury trial is afforded in Title VII suits. See Marshall v. Electric Hose \& Rubber Co., 12 Fair Empl. Prac. Cas. 1134 (D. Del. 1976).

127 The Sixth Circuit in Morelock, perhaps attempting to harmonize its holding with prior case law, intimated that the case at bar might be distinguishable from the district court cases supporting the right to jury trial. The court noted that the leading case of Chilton v. National Cash Register Co., 370 F. Supp. 666 (S.D. Ohio 1974), may have turned on the fact that the plaintiff had not sought equitable relief. $546 \mathrm{~F} .2 \mathrm{~d}$ at $689 \mathrm{n} .17$. This distinction would be valid only if the joinder of equitable claims with money claims changes the nature of otherwise legal issues, a possibility foreclosed by Beacon Theatres and Dairy Queen. Moreover, even though the only issue before the Fourth Circuit in Pons was the right to a jury determination of issues underlying the claim for lost wages, the plaintiff had joined a claim for reinstatement. 549 F.2d at 951 .

${ }^{123}$ This conclusion is supported by the court's suggestion that the Chilton court may have erred in failing to consider the ADEA's "close similarity with Title VII or the import of 29 U.S.C. § 626(c)." 546 F.2d 682, 689 n.17 (6th Cir. 1976).

12. Cases holding that the right to jury trial attaches in ADEA private suits seeking back pay are Bertrand v. Orkin Exterminating Co., 419 F. Supp. 423 (N.D. 1ll. 1976); Murphy v. American Motors Sales Corp., 410 F. Supp. 1403 (N.D. Ga. 1976); Cleverly v. Western Elec. Co., 69 F.R.D. 348 (W.D. Mo. 1975); Chilton v. National Cash Register Co., 370 F. Supp. 680 (S.D. Ohio 1974). Jury trial was denied in Hannon v. Continential Nat'l Bank, 427 F. Supp. 215 (D. Colo. 1977); Ewald v. Great Atl. \& Pac. Tea Co., 73 F.R.D. 374 (E.D. Mich. 1976).

The question of the right to jury trial of issues raised by claims for liquidated damages has engendered confusion in the lower courts. The disagreement is largely one of statutory construction. There clearly is a right to jury trial in a $\$ 16(\mathrm{~b})$ FLSA claim for liquidated damages. Lewis v. Times Publishing Co., 185 F.2d 457 (5th Cir. 1950); Olearchick v. American Steel Foundries, 73 F. Supp. 273 (W.D. Pa. 1947). But the trial court is empowered under $\S 11$ of the Portal-to-Portal Act, 29 U.S.C. $\S 260$ (1970), to reduce or eliminate the award of liquidated damages if the employer satisfactorily demonstrates that he reasonably believed his conduct not to be in violation of the FLSA. This trial court function is similar to that practiced by the district courts in patent infringement suits under 35 U.S.C. $\S 284$ (1970). 
626 provides that the award of monetary relief is discretionary with the trial court. The Pons court did not reach the issue because it found that the term "legal relief" in section 626(c) settled the seventh amendment issue. If the statute is construed in this manner, Morelock is indefensible, since it effectively held that no issues or claims raised in private ADEA suits are legal in nature. In support of Pons it can be argued that Congress must have been aware of the significance of the law-equity distinction for jury trial purposes; therefore, the authorization of legal relief requires a jury trial when money relief is claimed. This reasoning is a likely explanation of the Pons concurrence, which found it unnecessary to reach the constitutional issue since it was thought that the statute itself confers a right to jury trial. ${ }^{130}$ In Morelock the court acknowledged that the ADEA "gives individuals the right to seek legal as well as equitable relief," 131 but interpreted this to signify only that the trial court may grant any appropriate monetary or injunctive relief. According to the Sixth Circuit the provisions of the ADEA vest the trial court with the authority, once a violation has been shown, to grant or withhold monetary relief as the equities of the case demand. If this interpretation is correct, it provides a convincing functional justification for denying jury trial.

The Morelock interpretation does not withstand close scrutiny, however. At first glance the authorization of remedies does suggest a grant of discretion to the trial court with respect to the relief in any particular case. But a more plausible explanation is that the provision shifts to the judiciary the task of determining the range of remedies available to ADEA plaintiffs. ${ }^{132}$ Since violations of the

Such a division of functions was upheld against a seventh amendment challenge in Swofford v. B \& W, Inc., 336 F.2d 406 (5th Cir.), cert. denied, 379 U.S. 962 (1965). See generally Comment, The Seventh Amendment and Civil Rights Statutes: History Adrift in a Maelstrom, 68 Nw. U.L. REv. 503, 523-24 (1973). The Chilton court ruled that there is no right to jury trial on the factual issues underlying a claim for liquidated damages in ADEA actions. The court concluded that since the ADEA incorporates the FLSA enforcement provisions it must also incorporate $\S 11$ of the Portal-to-Portal Act, which makes the willfulness of the violation a bench issue. The constructional error of this ruling was pointed out in the Cleverly case. The court in Cleverly noted that the ADEA incorporates only the FLSA provisions, not $\$ 11$. Moreover, the ADEA provides that a showing of willfulness is a prerequisite to the recovery of liquidated damages. 29 U.S.C. $\$ 626(\mathrm{~b})$ (1970). If Congress intended the Act to incorporate $\S 11$, this prerequisite would be mere surplusage. Since the mode of trial for liquidated damages claims is not addressed by the Act, the Cleverly court looked to the seventh amendment and held jury trial was required. 69 F.R.D. at 352.

130 "Since the statute settles the controversy, I find no occasion for embarking on the constitutional quest which my brothers pursue." 549 F.2d at 954 . (Butzner, J., concurring).

${ }^{131}$ Morelock v. NCR Corp., 546 F.2d 682, 688 (6th Cir. 1976).

${ }_{132}$ It may be that the broad language of the Title VII enforcement provision, see note 77 supra, was intended to have a similar import. Under this view the lower courts-and the 
ADEA may harm a wide variety of employees and applicants in ways that could not all have been foreseen prior to the passage of the Act, Congress probably intended the courts to develop the law of age discrimination remedies because they would be more familiar with the practical operation of the statute. The flexibility accorded the courts to develop a body of remedial tools has no relevance to the nature of the trial court function for seventh amendment purposes. The courts often imply remedies where none have been expressly authorized, but the fact that a remedy is judicially implied does not justify treating the award of relief as equitable and wholly a matter of trial court dispensation. ${ }^{133}$ A legislative directive to the courts to exercise this law-making function should affect neither the nature of the remedy nor the role of the trial bench. Morelock may therefore be unsound in suggesting that section 626 authorizes a trial court to withhold money relief in its discretion once the plaintiff proves a violation.

Furthermore, the interrelationship of the FLSA enforcement provision and ADEA section 626 can be interpreted to support the Fourth Circuit's decision in Pons. Although Pons and the district court decisions fail to address the implications of the language of section 626, Morelock errs the other way by ignoring the effect of the Act's incorporation of the FLSA enforcement scheme. One of the "procedures" of FLSA private actions arguably incorporated into the ADEA is jury trial when requested. ${ }^{134}$ The incorporated language of section 16(b) providing that employers in violation "shall be liable" to the employees ${ }^{135}$ can be read to indicate entitlements in private ADEA actions analogous to those granted by section $16(\mathrm{~b})$.

Supreme Court in Curtis-erred in viewing that statute as vesting discretionary powers in the trial courts. See Comment, Jury Trial in Employment Discrimination Cases-Constitutionally Mandated? 53 TEx. L. REv. 483, 503 n.128 (1975). However, the view that Title VII courts are courts of equity is well entrenched and may be desirable in view of the complexity of Title VII actions. Even in narrowly constricting trial court discretion under Title VII in Albemarle Paper Co. v. Moody, 422 U.S. 405 (1976), the Court recognized the practical necessity for retaining a zone in which equitable considerations might operate. See generally 61 Cornell L. Rev. 460 (1976).

133 In Bivens v. Six Unknown Named Agents, 403 U.S. 388 (1971), the Supreme Court recognized a tort remedy for victims of searches and seizures in violation of the fourth amendment. Employing language strikingly similar to that of $\S 626$, Justice Harlan stated: "II]n suits for damages based on violations of federal statutes lacking any express authorization of a damage remedy, this Court has authorized such relief where, in its view, damages are necessary to effectuate the Congressional policy underpinning the substantive provisions of the statute." Id. at 402 (Harlan, J., concurring). No plausible argument could be made that Bivens-type damages are discretionary with the trial court once a violation has been proven simply because the remedy is judicially implied.

13 See text and notes at notes 69-71 supra.

13529 U.S.C. $\$ 216$ (b) (1970 \& Supp. IV 1974). 
Given the ambiguity of the ADEA provisions and the absence of Supreme Court interpretation, section 626 may be open to a construction vesting equitable discretion in the trial courts if the practicalities of administering the Act demand that private plaintiffs' rights be treated as less than absolute. The Sixth Circuit's analogy to section 17 of the FLSA suggests such a rationale. Like section 626, the language of FLSA section 17 leaves unclear the nature of the rights to be asserted. ${ }^{136}$ The courts have buttressed their conclusion that monetary relief under section 17 is discretionary by emphasizing the practical need for equitable balancing in such proceedings. ${ }^{137}$ The justification for denying monetary relief otherwise proper in FLSA Secretary actions is often found in the harm that might be inflicted upon the defendant's employees-and perhaps upon the community-if a court ordered plant-wide payment of all statutory deficiencies. In such cases awards are withheld on the theory that full relief is in the nature of a windfall, or that the detriments that may flow from a compensation order outweigh the benefits to the employee class. These justifications for judicial discretion are weaker in age discrimination suits. Such weighing of the equities is presumptively inappropriate in remedying unlawful discrimination. Antidiscrimination remedies are designed to rectify employer violations that have in the past favored third parties in derogation of the plaintiffs' rights. Basing a denial of money relief on judicial unwillingness to expose that previously favored class to the potentially adverse consequences of an award may sanction discrimination and preserve its effects. Furthermore, unlike the section 17 money remedy, the ADEA remedy is unlikely to work to the detriment of the class sought to be protected. Although these considerations do not conclusively determine the nature of the rights created by antidiscrimination legislation, ${ }^{138}$ they remove the major

136 See text and notes at notes 88-90 supra.

137 See text and notes at notes 92-94 supra.

13* The Title VII cases declaring the rights under that statute to be equitable in nature, see text and notes at notes 48,52 supra, would be difficult to justify but for the Supreme Court's statement in Curtis that the statutory language clearly commits the back pay award to the discretion of the trial judge. See text and notes at notes 50-54 supra.

The structure of the ADEA enforcement scheme might be interpreted as evidencing a congressional unwillingness to vest absolute rights in private plaintiffs. Under the statutory scheme, private plaintiffs must inform the Secretary of intent to file suit so that he can initiate conciliation efforts. 29 U.S.C. $\$ 626$ (d) (1970). Private rights lapse upon the Secretary's filing suit. Id. $\$ 626$ (c). The emphasis on informal conciliation might suggest that the district courts are intended to perform an equitable, conciliatory role as well. However, the importance of conciliation to the statutory plan supports the opposite conclusion. Employers will have a greater incentive to settle at the conciliation stage if they know that pleas to the equitable discretion of the decision maker will be foreclosed once a private suit reaches the 
justification for construing an ambiguous statute to reach the conclusion of the Morelock case, especially in the absence of judicial precedent establishing the discretionary nature of ADEA relief in private actions. ${ }^{139}$

Once the trial court's lack of discretion in awarding relief is recognized, the right to a jury trial in private actions under the ADEA seems clear. After Dairy Queen monetary relief is presumptively legal in nature. ${ }^{140}$ If the plaintiffs are entitled to monetary relief upon proof of a violation and harm, no functional justification exists for denying jury trial unless the computational tasks involved are beyond the capabilities of a jury. ${ }^{141}$ There is no reason to doubt the conclusion of the Fourth Circuit in Pons "that the computation of such an award would not be beyond the practical capabilities of a jury." 142 Private ADEA claims for monetary relief of any form therefore raise issues triable by a jury as a matter of constitutional right.

C. The Right to Jury Trial in ADEA Actions Brought by the Secretary of Labor

1. Suits Analogous to Actions Under FLSA Section 17. Only two cases have considered the jury trial issue in ADEA actions brought by the Secretary. In Hodgson $v$. Bowman, ${ }^{143}$ the court summarily granted a motion to strike the demand for jury trial on the authority of the leading cases denying jury trial in cases under section 17 of the FLSA. In Brennan v. International Harvester Co., ${ }^{144}$ the court, apparently viewing the ADEA suit as an action brought under FLSA section $17,{ }^{145}$ stated that the joinder of a claim for back pay did not affect the equitable nature of the action. The brief opinion does not consider the impact of the language of section

district court. The role of conciliation in the enforcement scheme is fortified by vesting absolute rights in private claimants once the prerequisites to suit are satisfied.

13 No cases have been found denying relief to a private claimant who has proven unlawful discrimination.

wo See text and notes at notes 25-30 supra.

't1 One functional justification for denying jury trial in Title VII suits is the possibility of jury racial bias. See generally Comment, The Right to Jury Trial Under Title VII of the Civil Rights Act of 1964, 37 U. CHI. L. REv. 167 (1969). Jury bias is not a likely danger in age discrimination actions.

142549 F.2d at 954.

1134 Empl. Prac. Dec. 5379 (E.D. Tenn. 1971).

is 7 Empl. Prac. Dec. 6904 (N.D. Ill. 1974).

is The Secretary also views ADEA actions as arising under the pertinent FLSA enforcement sections. Telephone interview with Gilbert Drucker, Counsel for Employment Standards Administration, Chicago Regional Office of the U.S. Department of Labor. 
626(b) of the ADEA empowering the court to award "such legal and equitable relief as may be appropriate." ${ }^{146}$ Nevertheless, wages lost because of unlawful discrimination clearly fall within the category of amounts "deemed to be unpaid minimum wages or unpaid overtime compensation for the purposes of [sections 16 and 17 of the FLSA]." 147 The procedures of the FLSA provide that in Secretary actions relief is to issue "for cause shown," 148 suggesting that once a violation is proved, relief is within the court's equitable discretion. ${ }^{149}$ Section 626(b)'s incorporation of section 17's procedures might, therefore, imply that monetary relief in ADEA Secretary actions is also discretionary with the court.

Although one court of appeals construing section $626(\mathrm{~b})$ concluded, in dictum, that "[s]pecific questions concerning damages or other relief are within the equitable discretion of the district court," 150 the hybrid nature of the ADEA enforcement provisions frustrates any attempt to resolve such questions by reference to language in the FLSA. Since the draftsmen probably did not consider the discretion issue, the answer must be found outside the words of the statute.

An assessment of the necessities of public enforcement proceedings supports the view that relief in ADEA suits by the Secretary should be discretionary. The public enforcement action is inherently more likely than private actions to involve the adjudication of numerous conflicting interests. ${ }^{151}$ The interests of applicants denied employment for unlawful reasons may clash with those of employees merely denied promotion, and with those of employees discharged because of age, especially where the defendant firm has so flagrantly violated the Act that only a small percentage of discriminatees can be awarded employment. It is conceivable that many actions by the Secretary may require trading off hiring or reinstatement orders

${ }^{146}$ As noted above, this language is ambiguous; it appears to be jurisdictional and may refer to either private or public suits or both. See text and note at note 103 supra.

14729 U.S.C. \$ 626(b) (1970); see Brennan v. Ace Hardware Corp., 7 Empl. Prac. Dec. 7185, 7189 (8th Cir. 1974); Monroe v. Penn-Dixie Cement Corp., 335 F. Supp. 231, 234-35 (N.D. Ga. 1971) (dictum).

148 29 U.S.C. \& 217 (1970).

14 See text and note at note 90 supra.

${ }^{150}$ Brennan v. Ace Hardware Corp., 7 Empl. Prac. Dec. 7185, 7189 (8th Cir. 1974).

151 But the Department of Labor often will pursue age discrimination claims on behalf of an individual employee in a "one-on-one" action, particularly when the suit involves a legal issue of general importance or a question concerning the Act's application to a defendant's practices that is likely to have important consequences for other employees. Telephone interview with Gilbert Drucker, Counsel for Employment Standards Administration, Chicago Regional Office of the U.S. Department of Labor. 
against monetary awards. Thus public enforcement actions are likely to involve precisely the kind of multiple interest disputes that historically spurred the evolution of a significant part of equity's jurisdiction. The recognition of entitlements, and hence the right to jury trial when demanded, would impede the equitable accomodation of the parties' interests. The possibility that some ADEA Secretary actions will require delicate judicial accommodations may justify uniformly denying jury trial in such actions. There is no necessary inconsistency in vesting entitlements in employees yet defeating those entitlements when the Secretary files suit. The enforcement scheme of the Act appears well designed to single out for equitable, nonjury treatment just those cases in which the interests of discriminatees are likely to conflict. ${ }^{152}$

2. Suits Analogous to Actions Under FLSA Section 16(c) and Claims for Liquidated Damages. Although section 626(b) of the ADEA by its terms authorizes suits by the Secretary analogous to those possible under both section 17 and section 16(c) of the FLSA, ${ }^{153}$ the expansive language of the ADEA enforcement provisions may have effectively eliminated any distinction between the two types of Secretary suits. Since the ADEA gives private plaintiffs the right to equitable as well as legal relief, ${ }^{154}$ the Secretary bringing a representative action analogous to a suit under FLSA section 16(c) is not limited to legal remedies. ${ }^{155}$ Thus the statutory language does not unambiguously determine the legal or equitable "nature" of an ADEA action analogous to an FLSA section 16(c) action. If the ADEA is interpreted as incorporating the 1974 amendments to FLSA section $16(c),{ }^{156}$ the need for judicial discretion in remedies and consequently the nature of the action under the discretion crite-

132 The ADEA's reliance on settlement machinery also supports giving the court discretion in suits by the Secretary. The Secretary may sue in order to protect a compromise settlement by preempting private rights of action by persons who have not agreed with the compromise. In such a case the court could not protect the compromise if amounts due discriminatees were treated as entitlements.

13329 U.S.C. $\$ 626($ b) (1970).

13429 U.S.C. $\$ 626(\mathrm{~b}),(\mathrm{c})(1970)$; see text and notes at notes 103-06 supra.

${ }_{15 s}$ The "jurisdictional" language of $\S 626(\mathrm{~b})$ also arguably supports the Secretary's authority to seek both equitable and legal relief in actions analogous to FLSA \& 16(c). See text and note at note 103 supra.

ist See note 64 supra. A more restrictive version of $\S 16$ (c) was in force when the ADEA was adopted in 1967. If the ADEA is held to incorporate only this version, the need for judicial discretion over remedies in actions analogous to FLSA $\$ 16(\mathrm{c})$ actions is much weaker, and a strong argument can be made for treating such actions as legal in nature. The expansive jurisdictional language in $\S 626$ (b) of the ADEA, see text and note at note 103 supra, suggests that the courts may make available under the ADEA the expanded relief created by the 1974 amendments to $\S 16(\mathrm{c})$ of the FLSA. 
rion appears identical in any ADEA suit brought by the Secretary regardless of its label.

An important exception to this generalization would arise if the Secretary were to seek liquidated damages under the ADEA. ${ }^{157}$ Liquidated damages under the ADEA are punitive because they may be awarded only in cases of "willful" violations. ${ }^{158}$ Since equity traditionally refused to impose penalties, ${ }^{159}$ the "historical practice" branch of the Ross test supports the existence of the right to jury trial of fact issues underlying claims for exemplary damages. ${ }^{160} \mathrm{Be}$ cause Beacon Theatres requires that legal claims resting on factual issues common to equitable claims be tried first, ${ }^{161}$ the practical effect of classifying claims for liquidated damages as legal is to allow the right to jury trial on key issues in any case where the Secretary seeks liquidated damages.

\section{The Limits of the Discretion Criterion}

While the discretion criterion provides a useful analytic tool for resolving the jury trial issue in new statutory causes of action, the actual application of the criterion in the context of the FLSA and the ADEA indicates that its value is limited. First, the discretion criterion must be recognized as secondary to the traditional historical tests for determining the legal or equitable nature of an action. The degree of trial court discretion is a functional criterion that is legitimized by its relationship to the historical nature of actions in equity; the criterion relies on the generalization that discretion is the traditional hallmark of equitable jurisdiction. Insofar as this generalization is accurate, the discretion criterion should yield the same result as theion is accurate, the discretion criterion should yield the same result as the historical tests. ${ }^{162}$ When the historical

157 The ADEA is ambiguous on whether the Secretary may seek liquidated damages. The Secretary was not expressly authorized to seek liquidated damages under $\S 16$ (c) of the FLSA until the 1974 amendments. See note 64 supra. The broad language of ADEA $\$ 626(\mathrm{~b})$ may authorize the courts to grant such relief in actions by the Secretary, but "liquidated damages" is noticeably absent from the list of examples of relief a court is authorized to grant "in any action." See 29 U.S.C. $\$ 626$ (b) (1970); text and note at note 103 supra.

${ }^{158} 29$ U.S.C. $\S 626(\mathrm{~b})(1970)$.

159 "Liquidated damages, having aspects of both actual and punitive damages, are a traditionally legal form of relief." Cleverly v. Western Elec. Co., 69 F.R.D. 348, 352 (W.D. Mo. 1975).

${ }^{160}$ See note 126 supra.

161 See text and note at note 24 supra.

162 The generalization is supported by Plucknett's view of the historical nature of the common law. He describes the ossification of the common law as follows:

Our common lawyers in fact are beginning to feel the attraction of the "legal mind", the delight of pushing a principle as far as it will go and even further, and were enthusiastic over their first lessons in the rigor juris. . . . [T] he real question which they had to 
analogies are clear, as in actions for unpaid compensation under section 16 of the FLSA or for liquidated damages, the discretion criterion is superfluous. It is useful only when the historical tests yield ambiguous results.

Second, even when the discretion criterion is appropriately applied, it suffers some inherent limitations. When a statute is ambiguous as to the latitude of discretion allowed the trial court-as is the ADEA-a court using the discretion criterion must rely on rough generalizations about the need for judicial flexibility. The need for judicial discretion in a particular type of action is seldom uncontroversial, ${ }^{163}$ and even if discretion is necessary in some cases, a rule denying the right to jury trial in all cases will deprive parties of a putatively valuable right in cases requiring no discretion. ${ }^{164}$

These inherent limitations of the discretion criterion may be easier to tolerate if courts recognize a third limitation on the criterion's usefulness-the possibility that the need for judicial discretion in a particular action may change over time. The most important aspect of the Beacon Theatres opinion-the Court's adoption of a dynamic seventh amendment test-requires that the vitality of the reasons for denying jury trial be continually tested. Should it become apparent that judicial discretion to deny relief-whether in

face was how the future of the law should be developed. Was it to be a system of strict rule, mainly procedural, or was there to be a broader principle of conscience, reason, natural justice, equity? Plainly there were two points of view on this matter in the reign of Edward II, but it must have been fairly evident by the middle of the century that the stricter party had won. The law no doubt grew in content, but its growth was within a framework of technical doctrine and procedure ....

T. PlucknetT, A CONCISE History OF THE COMmON LAW 642 (4th ed. 1948). Concerning equity, Plucknett remarks: "[ []$n$ one sense at least, equity is inseparable from the duty of the king to do justice and his power to exercise discretion .... The characteristic of our classical equity is the idea of conscience ...." Id. at 643 .

${ }^{163}$ The controversy over the need for discretion in ADEA private and public suits is illustrative. While this comment argues that the reasons for discretion that are decisive in actions under $\S 17$ of the FLSA do not apply to ADEA actions, see text at notes 137-39 supra, one might argue that some characteristics of ADEA suits make judicial discretion more necessary than in FLSA suits. See text at notes 101-02 supra.

16 The traditional classification of injunctions as equitable actions is arguably also based in part on generalizations about the need for discretion, see note 152 supra, but classification by such generalizations seems more suspect when a functional, rather than historical, approach is being consciously used. Courts should be particularly hesitant to deny jury trial on the basis of rough generalizations when monetary relief is in issue.

A case-by-case approach, allowing the trial judge to determine the jury trial issue according to his perception of the basic nature of the action, would be difficult to administer because the need for discretion in a particular case will seldom be apparent at the stage at which the mode of trial is determined. A compromise position between a uniform rule and a case-bycase approach might classify actions by characteristics thought to be indicative of the need for judicial discretion-e.g., the number of plaintiffs, or the possibilities for giving full relief to parties with potentially conflicting interests. 
ADEA, FLSA, or Title VII actions-is nonexistent, then the right to jury trial would arise. ${ }^{165}$

\section{ConcLusion}

The seventh amendment guarantees the right to jury trial in new statutory causes of action of a legal nature brought in federal courts. Broad language in the Supreme Court's opinions in Beacon Theatres, Inc. v. Westover and Dairy Queen, Inc. v. Wood implied that all statutory actions for monetary relief are of a legal nature for jury trial purposes absent special circumstances that functionally disqualify a jury. The lower courts have ignored the implications of these decisions in ruling that no right to jury trial attaches in Title VII actions or in actions brought by the Secretary of Labor under section 17 of the Fair Labor Standards Act and under the Age Discrimination in Employment Act.

The reticence of these courts has been vindicated by dicta in the Supreme Court's opinion in Curtis v. Loether implicitly affirming Congress' power to create new equitable causes of action in which money relief may be granted. The Court appears to approve the reasoning of lower court decisions denying jury trial in Title VII actions on the ground that awards of monetary relief are discretionary with the bench. This reasoning is based on the generalization that discretion is a hallmark of equitable jurisdiction. The discretion criterion can be assimilated to the Supreme Court's seventh amendment decisions by viewing it as a particular manifestation of the functional test stated by the Court in Ross $v$. Bernhard: if a statute contemplates judicial discretion to deny relief despite a showing of violation and harm, trial by jury is inappropriate and unnecessary.

The discretion criterion must be applied cautiously and with respect for its limitations. The criterion ratifies long-standing case law denying jury trial in actions by the Secretary of Labor under section 17 of the FLSA, for section 17 appears to entrust trial courts with equitable discretion. Where the enforcement provision is more ambiguous, as in the ADEA, the courts must inquire whether the general nature of the action requires equitable adjudication. If so, the right to jury trial is precluded by functional considerations. Under this analysis ADEA Secretary actions not seeking liquidated damages are not triable to a jury as of right. But the dynamic

Ios Justice Rehnquist intimated as much with respect to Title VII actions in his Albemarle concurrence. See note 55 supra. 
character of the the Supreme Court's seventh amendment analysis in Beacon Theatres demands that this conclusion be viewed as provisional only, subject to change if developments in age discrimination law should so crystallize the prerequisites to relief that no discretion is left to the court.

The Sixth Circuit recently recognized the legitimacy of the discretion criterion in Morelock v. NCR Corp., where the court denied the right to jury trial in a private action under the ADEA. Unfortunately the court's application of the criterion was overly mechanical. Faced with ambiguous statutory language, the court resolved against recognizing a right to jury trial despite the absence of compelling reasons for exercising equitable discretion in private ADEA actions. The denial of jury trial in Morelock flouts the still vital principle of Beacon Theatres that money claims are presumptively legal in nature and are therefore, absent countervailing functional considerations, triable to a jury as of right. 